Jurnal Ilmu-Ilmu Peternakan 25 (3): 37 - 44

ISSN: 0852-3681

E-ISSN: 2443-0765

CFakultas Peternakan UB, http://jiip.ub.ac.id/

\title{
Pengaruh pemberian aditif cair buah naga merah (Hylocereus polyrhizus) terhadap performa burung puyuh betina umur 16-50 hari
}

\author{
Vernanda Windi Laksmita, Fajar Wahyono dan Istna Mangisah \\ Fakultas Peternakan dan Pertanian Universitas Diponegoro \\ vernandalaksmita@gmail.com
}

\begin{abstract}
The research aimed to know the effect of a liquid additive red dragon fruit (Hylocereus polyrhizus) on the performance of quail females aged 16-50 days with different treatment. The research was conducted at cage of Non Ruminant Feed Nutrition Science Laboratory, Department of Animal Nutrition and Feed, Animal Agriculture Faculty, Diponegoro University on September-December 2015. The research design based on Completely Randomized Design (CRD), with the control treatment and treatment liquid additives red dragon fruit twice a day, once a day and two days one. Each treatment was 5 times repeated. The parameters measured were feed consumption, weight gain, feed conversion and feed efficiency. The results showed that the treatment was not significant $(\mathrm{P}>0.05)$ effects on feed consumption, weight gain, feed conversion and feed efficiency in quail. The average of T0, T1, T2 and T3 which feed consumption of $15.64 ; 15.85 ; 15.67$ and $15.80 \mathrm{~g} /$ head/day, weight gain of 118.70 ; $121.00 ; 124.20$ and $126.90 \mathrm{~g} / \mathrm{head}$, feed conversion of $4.62 ; 4.58 ; 4.43$ and 4.38 and feed efficiency of $21.68 ; 21.98 ; 22.65$ and $22.92 \%$. The conclusion is the treatment of a liquid additive red dragon fruit (Hylocereus polyrhizus) on quail resulted in feed consumption, weight gain, feed conversion and feed efficiency were similar to the control treatment that has not been able to improve the performance of quail aged 16-50 days.
\end{abstract}

Keywords : quail, red dragon fruit, feed consumption, performances

\section{PENDAHULUAN}

Burung puyuh merupakan salah satu komoditi unggas dari genus Coturnix yang dapat dimanfaatkan sebagai penghasil telur dan daging. Burung puyuh betina akan mulai bertelur pertama kali pada umur 42-50 hari (Rachmat et al., 2007). Produktifitas burung puyuh dapat mencapai 250-300 butir/tahun dengan berat rata-rata $10 \mathrm{~g} / \mathrm{butir}$. Pemeliharaan pada fase starter dan grower sangat penting untuk diperhatikan agar potensi burung puyuh dapat maksimal. Masa pertumbuhan burung puyuh membutuhkan energi yang cukup untuk memenuhi kebutuhan nutrisinya.

Pemenuhan kebutuhan nutrisi baik dari segi kualitas maupun kuantitas sangat diperlukan karena nutrien merupakan salah satu faktor penting dalam menunjang produktivitas ternak. Oleh sebab itu peternak sering memberikan zat aditif dengan cara 
mencampurkan dalam ransum atau dilarutkan dalam air minum. Salah satu alternatif zat aditif yang dapat diberikan pada puyuh adalah buah naga merah (Hylocereus polyrhizus). Buah naga merah memiliki kandungan zat nutrisi yang bermanfaat yaitu vitamin. Akan tetapi penambahan zat aditif dapat meningkatkan biaya produksi. Sehingga alternatif yang dapat dilakukan untuk mengatasi kendala tersebut adalah dengan membudidayakan sendiri tanaman sumber zat aditif, sehingga harga yang dikeluarkan akan lebih murah jika dibandingkan dengan buatan pabrik. Bahan organik dianggap lebih mudah untuk diaplikasikan oleh peternak karena lebih aman dan tidak meninggalkan residu dalam produk ternak.

Buah naga merah memiliki
kandungan nutrisi vitamin yang
optimal, diantaranya adalah vitamin C
bersifat antioksidan yang dapat
mengurangi radikal bebas,
meningkatkan ketahanan tubuh terhadap stres serta menurunkan $\mathrm{pH}$ saluran pencernaan. Kandungan vitamin lain yang ada pada zat aditif alami ini adalah vitamin B dengan manfaat memberi pengaruh padai nafsu makan ternak. Vitamin sangat penting untuk menunjang pertumbuhan, kesehatan dan dibutuhkan dalam tubuh agar penyerapan nutrisi menjadi lebih efisien sehingga diharapkan dengan pemberian aditif cair buah naga merah dapat meningkatkan konsumsi ransum dan performa burung puyuh pada masa pertumbuhan.

Tujuan dari penelitian ini adalah untuk mengetahui pengaruh pemberian aditif cair buah naga merah terhadap performa burung puyuh betina umur 1650 hari. Performa burung puyuh dilihat dari konsumsi ransum, pertambahan bobot badan, konversi ransum dan efisiensi ransum.

\section{MATERI DAN METODE}

Penelitian telah dilaksanakan pada bulan September-Desember 2015 di Kandang Non Ruminansia Laboratorium Ilmu Nutrisi Pakan, Laboratorium Teknologi dan Rekayasa Pangan, Fakultas Peternakan dan Pertanian Universitas Diponegoro, Semarang.

Materi yang digunakan adalah 200 ekor burung puyuh betina umur 7 hari dengan bobot badan 13,61 $\pm 0,49 \mathrm{~g}$, ransum yang digunakan tersusun atas enam bahan pakan yang terdiri dari tepung ikan, jagung kuning, konsentrat CP 124, bekatul, bungkil kedelai dan top mix dengan protein kasar 20,91\% dan EM 2763,93 kkal/kg. Aditif cair yang digunakan yaitu buah naga merah. Peralatan yang digunakan adalah kandang battery sebanyak 20 petak kandang dimana setiap petak kandang diisi dengan 10 ekor puyuh, tempat pakan dan minum, blender dan timbangan.

Penelitian telah dilaksanakan dalam beberapa tahap kegiatan antara lain tahap persiapan, perlakuan dan pengumpulan data.

Tahap persiapan yang meliputi persiapan kandang, pengadaan dan penyusunan ransum, analisis kandungan nutrien ransum, pengadaan burung puyuh, penimbangan bobot badan awal burung puyuh dan pembuatan zat aditif cair buah naga merah dengan cara menimbang $100 \mathrm{~g}$ daging buah naga merah dan dipotong menjadi bagian yang lebih kecil. Memasukkan potongan tersebut ke dalam blender dan menambahkan $500 \mathrm{ml}$ air (perbandingan 1:5) kemudian di blender hingga tercampur rata. Campuran buah naga kemudian disaring untuk memisahkan biji buah naga dengan bagian aditif cair.

Tahap perlakuan dilaksanakan pada burung puyuh betina umur 16-50 hari. Ransum diberikan secara terbatas 
terkontrol dua kali sehari pada pagi dan sore hari, untuk minum diberikan secara ad libitum setiap hari dan aditif cair buah naga merah diberikan dengan dosis pemberian $5 \mathrm{ml} / \mathrm{ekor}$, tiap kali pemberian ditempatkan pada wadah tempat minum tersendiri. Sebelum pemberian aditif cair buah naga merah, air minum diambil terlebih dahulu satu jam sebelum pemberian.

Pemberian aditif cair buah naga merah pada pagi hari diberikan pukul
10.00 WIB dan pada perlakuan T1 diberikan dua kali sehari yaitu pada pukul 10.00 dan 14.00 WIB. Penimbangan sisa pakan dilakukan setiap hari sebelum pemberian ransum pertama di pagi hari. Pada setiap minggunya dilakukan kegiatan penimbangan bobot badan, perhitungan konversi ransum serta efisiensi ransum. Brikut merupakan data komposisi ransum yang disajikan pada Tabel 1 .

Tabel 1.Komposisi ransum dan kandungan nutrisi ransum penelitian

\begin{tabular}{|c|c|}
\hline Bahan Pakan & Komposisi \\
\hline & ---- \% ---- \\
\hline Bekatul & 10,60 \\
\hline Jagung Kuning & 43,00 \\
\hline Konsentrat CP 124 & 30,00 \\
\hline Tepung Ikan & 8,00 \\
\hline bungkil kedelai & 8,00 \\
\hline top mix & 0,40 \\
\hline TOTAL & 100 \\
\hline \multicolumn{2}{|l|}{ Kandungan Nutrisi } \\
\hline $\begin{array}{l}\text { Energi Metabolis } \\
(\mathrm{kkal} / \mathrm{kg})^{* *}\end{array}$ & 2763,93 \\
\hline Protein $(\%)^{*}$ & 20,91 \\
\hline Lemak $(\%)^{*}$ & 2,12 \\
\hline Serat Kasar $(\%)^{*}$ & 4,20 \\
\hline $\mathrm{Abu}(\%)^{*}$ & 8,58 \\
\hline Kadar kalsium $(\%)^{* *}$ & 0,65 \\
\hline Kadar fosfor $(\%)^{* *}$ & 0,65 \\
\hline
\end{tabular}

Keterangan :

*Hasil analisis proksimat Laboratorium Balai Pengkajian Teknologi Pertanian Jawa Tengah, Ungaran (2015).

** Hasil analisis Laboratorium Ilmu Nutrisi dan Pakan, Fakultas Peternakan dan Pertanian, Universitas Diponegoro, Semarang (2015).

Penelitian ini menggunakan Rancangan Acak Lengkap dengan 4 perlakuan dan 5 ulangan, masingmasing kandang terdiri dari 10 ekor puyuh betina. Perlakuan yang diberikan adalah: $(\mathrm{T} 0=$ kontrol, $\mathrm{T} 1=$ pemberian zat aditif cair buah naga dua kali sehari, $\mathrm{T} 2$ = pemberian zat aditif cair buah naga satu kali sehari, T3 = pemberian zat aditif cair buah naga dua hari satu kali). Parameter yang diamati dalam penelitian ini adalah :

1. Konsumsi ransum = ransum yang diberikan dikurangi sisa ransum, dilakukan setiap hari (g/ekor/hari)

2. Pertambahan Bobot Badan $(\mathrm{PBB})=$ bobot badan akhir dikurangi bobot badan awal pemeliharaan (g/ekor) 


\begin{tabular}{|c|c|c|}
\hline $\begin{array}{l}\text { Konversi ransum } \\
\text { konsumsi ransum }\end{array}$ & $=$ & $\begin{array}{l}\text { HASIL DAN PEMBAHASAN } \\
\text { Pemberian zat aditif cair buah }\end{array}$ \\
\hline pertambahan bobot badan & & naga merah ( $\mathrm{T} 1, \mathrm{~T} 2$ dan $\mathrm{T} 3$ ) belum \\
\hline $\begin{array}{l}\text { 4. Efisiensi ransum } \\
\text { pertambahan bobot badan }\end{array}$ & $=$ & $\begin{array}{l}\text { mampu menghasilkan performa yang } \\
\text { baik pada burung puyuh betina umur }\end{array}$ \\
\hline konsumsi ransum & & $\begin{array}{l}\text { 16-50 hari dari segi konsumsi ransum, } \\
\text { pertambahan bobot badan, efisiensi } \\
\text { ransum dan konversi ransum yang } \\
\text { ditampilkan pada Tabel } 2 \text { berikut. }\end{array}$ \\
\hline
\end{tabular}

Tabel 2. Pengaruh perlakuan terhadap konsumsi ransum, pbb, konversi ransum dan efisiensi ransum

\begin{tabular}{lcccc}
\hline \multicolumn{1}{c}{ Perlakuan } & T0 & T1 & T2 & T3 \\
\hline Konsumsi Ransum* (g/ekor/hari) & 15,64 & 15,85 & 15,67 & 15,80 \\
PBB* (g/ekor) & 118,70 & 121,00 & 124,20 & 126,90 \\
Konversi Ransum* & 4,62 & 4,58 & 4,43 & 4,38 \\
Efisiensi Ransum* (\%) & 21,68 & 21,98 & 22,65 & 22,92 \\
\hline
\end{tabular}

Keterangan: * Nilai rata-rata tidak menunjukkan perbedaan $(\mathrm{P}>0,05)$

\section{Konsumsi ransum}

Nilai rata-rata konsumsi ransum yang diperoleh lebih rendah dari pendapat Hardjosworo (1992) yang menyatakan bahwa konsumsi burung puyuh pada umur lebih dari 5 minggu adalah 20 g/ekor/hari.

Perlakuan T1 hingga T3 menunjukkan tidak berpengaruh nyata $(\mathrm{P}>0,05)$ dengan perlakuan kontrol (T0) karena ransum pada setiap perlakuan memiliki kandungan nutrien yang hampir sama, selain itu imbangan energi dan protein juga sama. Energi yang dikonsumsi pada perlakuan T1, T2 dan T3 dari pakan maupun aditif cair buah naga merah sama yaitu $2763,93 \mathrm{kkal} / \mathrm{kg}$. Menurut Wahju (2004) faktor utama yang mempengaruhi konsumsi ransum adalah kandungan energi metabolisme dalam pakan, imbangan nutrisi ransum, kesehatan, temperatur lingkungan, ruang tempat pakan, keadaan air minum dan aktivitas ternak.

Pemberian aditif cair buah naga merah diharapkan mampu meningkatkan konsumsi ransum karena memiliki kandungan vitamin $\mathrm{C}$ yang mampu mengurangi stres akibat suhu panas pada lingkungan sehingga akan mengkonsumsi ransum dengan jumlah lebih banyak. Sesuai dengan pendapat Subekti (2012) bahwa pemberian aditif vitamin $\mathrm{C}$ dapat mengurangi cekaman panas sehingga konsumsi ransum tidak akan terganggu. Selain vitamin C, vitamin $B$ berfungsi dalam pembentukan energi yang dapat memperbaiki saluran pencernaan dan akan meningkatkan nafsu makan. Menurut Patwary et al. (2013) buah naga merah mengandung vitamin $B$ yang berguna untuk meningkatkan nafsu makan. Namun, hasil penelitian menunjukkan tidak berpengaruh nyata pada konsumsi karena dosis pemberian aditif cair buah naga merah yang masih sedikit menyebabkan asupan vitamin B dan $\mathrm{C}$ tidak mempengaruhi cekaman panas.

Selain vitamin B dan C, kandungan gula dalam aditif cair buah naga merah juga cenderung meningkatkan konsumsi ransum perlakuan walaupun tidak berbeda nyata. Hal ini sesuai dengan pendapat 
Utari dkk. (2013) yang menyatakan bahwa kandungan gula dalam buah naga merah dapat berpengaruh pada energi metabolis yang merupakan komponen penting yang digunakan sebagai sumber energi bagi ternak. Maghfiroh dkk (2012) menambahkan bahwa kandungan energi yang sama pada ransum menyebabkan konsumsi ransum cenderung sama dan tidak berbeda jauh. Sedangkan menurut pendapat Anggorodi (1995) kandungan energi dalam pakan burung puyuh dapat mempengaruhi konsumsi pakan, semakin tinggi kandungan energi maka ransum yang dikonsumsi semakin berkurang. Data mengenai konsumsi energy dan protein pada burung puyuh ditampilkan pada Tabel 3 berikut.

Tabel 3. Konsumsi energi dan protein pada burung puyuh

\begin{tabular}{ccccc}
\hline Perlakuan & T0 & T1 & T2 & T3 \\
\hline Konsumsi Energi (kkal/ekor/hari) & 43,22 & 43,81 & 43,32 & 43,66 \\
Konsumsi Protein (g/ekor/hari) & 3,27 & 3,31 & 3,28 & 3,30 \\
\hline
\end{tabular}

Keterangan: Konsumsi energi dan konsumsi protein menunjukkan kisaran yang sama $(\mathrm{P}>0,05)$

Berdasarkan hasil penelitian menunjukkan bahwa konsumsi energi burung puyuh dalam kisaran normal yaitu sebesar $\pm 43 \mathrm{kkal} / \mathrm{ekor} / \mathrm{hari}$ (Tabel 3), sesuai dengan hasil penelitian Yatno dkk. (2008) yang menyatakan bahwa burung puyuh pada masa pertumbuhan memiliki kisaran konsumsi energi 26,71-51,35 kkal/ekor/hari. Tidak adanya pengaruh nyata ini karena konsumsi ransum yang sama. Kandungan energi dalam pakan dan aditif cair buah naga merah pada perlakuan belum dapat mempengaruhi konsumsi ransum, konsumsi energi dan konsumsi protein karena kadar EM ransum sama. Hal ini sesuai dengan pendapat Wahju (2004) yang menyatakan bahwa jika energi dalam pakan yang dikonsumsi sesuai dengan kebutuhannya, maka konsumsi pakan akan tinggi sedangkan jika kandungan energi melebihi kebutuhan, maka konsumsi pakan akan sedikit.

Rata-rata konsumsi protein pada perlakuan T1, T2 dan T3 sudah sesuai kebutuhan yaitu sebesar 3,31; 3,28; dan 3,30 g/ekor/hari. Hal ini sesuai dengan pendapat Yatno dkk. (2008) yang menyatakan bahwa konsumsi protein pada burung puyuh berumur 6 minggu adalah 3,39-4,53 g/ekor/hari dan menurut penelitian Widjastuti dan Kartasudjana (2006) konsumsi protein sebesar 3,49 g/ekor/hari telah cukup untuk memenuhi hidup pokok, pertumbuhan dan produksi telur pada burung puyuh. Penelitian ini tingkat protein ransumnya sama akibatnya konsumsi protein juga sama sehingga pemberian aditif cair buah naga tidak mempengaruhi kadar protein ransum. Hal ini sesuai dengan pendapat Irawan dkk. (2012) yang menyatakan bahwa konsumsi protein dipengaruhi oleh tingkat protein ransum, apabila tingkat protein dalam ransum semakin tinggi, maka konsumsi protein akan semakin meningkat.

\section{Pertambahan bobot badan}

Hasil penelitian menunjukkan bahwa rata-rata $\mathrm{PBB}$ burung puyuh tidak berpengaruh nyata $(\mathrm{P}>0,05)$. Tidak adanya perbedaan pertambahan bobot badan secara nyata dikarenakan jumlah konsumsi ransum sama (Tabel 2) dan konsumsi energi serta konsumsi protein (Tabel 3) yang sama pula. Asupan nutrisi vitamin dalam aditif cair 
buah naga merah belum mampu meningkatkan pertambahan bobot badan. Buah naga merah mengandung vitamin $B$ yang dapat meningkatakan nafsu makan akan tetapi belum nyata meningkatkan PBB. Hal ini sesuai dengan pendapat Patwary et al. (2013), bahwa vitamin B dapat meningkatkan nafsu makan. Menurut Kuswahyuni (1983) bahwa berat badan burung puyuh betina pada umur enam minggu berkisar 121,89-138,24 g.

Salah satu faktor yang mempengaruhi bobot badan adalah kualitas dan kuantitas pakan, dengan jumlah pemberian ransum dan kandungan nutrien ransum yang sama sehingga menghasilkan pertambahan bobot badan yang sama. Hal ini sesuai dengan pendapat Widjastuti dan Kartasudjana (2006) yang menyatakan bahwa bobot badan dipengaruhi oleh kualitas dan kuantitas pakan yang dikonsumsi. Goa dkk. (2015) menambahkan bahwa faktor yang mempengaruhi pertambahan bobot badan adalah jumlah pakan yang dikonsumsi, laju perjalanan pakan dalam saluran pencernaan, bentuk fisik pakan, komposisi pakan dan imbangan kandungan nutrisi pakan.

\section{Konversi ransum}

Hasil rerata konversi ransum perlakuan pemberian aditif cair buah naga merah T1, T2 dan T3 yang diperoleh termasuk dalam kisaran normal karena lebih efisien memanfaatkan ransum yang ada dibandingkan dengan perlakuan kontrol. Hal ini sesuai dengan hasil penelitian Mufti (1997) yang menyatakan bahwa rataan konversi ransum burung puyuh fase grower berkisar antara 4,03-4,73. Sedangkan menurut Hazim et al. (2010) angka konversi ransum burung puyuh idealnya adalah 3,76-4,71.
Konversi ransum erat kaitannya dengan konsumsi ransum dan pertambahan bobot badan ternak. Sesuai dengan pernyataan Achmanu dkk. (2011) yang menyatakan bahwa perbedaan konversi pakan disebabkan karena adanya perbedaan dalam konsumsi ransum dan pertambahan bobot badan. Menurut Amrulloh (2003) faktor yang mempengaruhi konversi ransum adalah kualitas ransum, teknik pemberian, bentuk dan konsumsi ransum serta bobot badan ternak.

\section{Efisiensi ransum}

Perlakuan dengan pemberian aditif cair buah naga merah tidak menurunkan atau menaikkan nilai efisiensi ransum secara signifikan. Pemberian aditif cair buah naga merah pada perlakuan T1, T2 dan T3 mengakibatkan efisiensi ransum yang cenderung lebih baik dibandingkan dengan ransum kontrol. Hal ini sesuai dengan pendapat Tillman et al. (1991) yang menyatakan bahwa efisiensi penggunaan ransum yang terbaik ditunjukkan dari semakin besar efisiensi pakan yang dihasilkan, semakin tinggi nilai efisiensi pakan menunjukkan ternak efisien dalam mengkonsumsi pakan untuk menghasilkan bobot badan yang ideal.

Kandungan vitamin C pada buah naga merah belum mampu meningkatkan nilai efisiensi ransum pada perlakuan ini dikarenakan dosis perlakuan yang diberikan terlalu sedikit. Hal ini tidak sesuai dengan pendapat Parakkasi (1983) yang menyatakan bahwa penambahan vitamin $\mathrm{C}$ dalam ransum dapat menaikkan bobot badan dan efisiensi penggunaan pakan. Asupan vitamin C pada puyuh yang masih sedikit menunjukkan bahwa dengan pemberian aditif cair buah naga merah kurang dapat meningkatkan efisiensi penggunaan ransum. 


\section{KESIMPULAN}

Berdasarkan hasil penelitian disimpulkan bahwa pemberian aditif cair buah naga merah (Hylocereus polyrhizus) sebanyak $5 \mathrm{ml} / \mathrm{ekor}$ dengan frekuensi pemberian dua kali sehari, satu kali sehari dan dua hari satu kali tidak meningkatkan performa burung puyuh umur 16-50 hari.

\section{DAFTAR PUSTAKA}

Achmanu, Muharlien dan Salaby. 2011. Pengaruh lantai kandang (rapat dan renggang) dan imbangan jantan betina terhadap konsumsi pakan, bobot telur, konversi pakan dan tebal kerabang pada burung puyuh. Jurnal Ternak Tropika. 12 (2): 1-14.

Amrulloh, I. K. 2003. Seri beternak mandiri: nutrisi ayam broiler. Lembaga Satu Gunung Budi, Bogor.

Anggorodi, R. 1995. Nutrisi ternak unggas. Cetakan I. PT. Gramedia Pustaka Utama, Jakarta.

Goa, S. E. L., Silitonga, L dan Yuanita, I. 2015. Substitusi ransum jadi dengan roti afkir terhadap performa burung puyuh (Coturnix coturnix japonica) umur starter sampai awal bertelur. Jurnal Ilmu Hewani Tropika. 4 (2): 61-65.

Hardjosworo, P. S., 1992. Beternak puyuh. Fakultas Peternakan IPB, Bogor.

Hazim, J., Al-Daraji, H. A. AlMashadani, W. K. Al-Wahyani, H. A. Mirza and A. S. AlHasani. 2010. Effect of dietary suplementation with different oil on productive and reproductive performance of quail. International Journal Poultry Science. 9 (5): 429 -435.
Irawan, I., Sunarti, D dan Mahfudz, L. D. 2012. Pengaruh pemberian pakan bebas pilih terhadap kecernaan protein burung puyuh (Coturnix coturnix japonica). Fakultas Peternakan dan Pertanian, Universitas Diponegoro, Semarang. Animal Agriculture Journal. 1 (2): 238245.

Kuswahyuni, I. R. 1983. Parameter genetik beberapa sifat produksi pada burung puyuh (Coturnix coturnix japonica). Fakultas Pascasarjana Institut Pertanian Bogor, Bogor. (Thesis).

Maghfiroh, K., Sukamto, B. dan Mahfudz, L. D. 2014. Penggunaan sorgum atau kulit pisang terhidrolisis terhadap retensi kalsium dan massa kalsium tulang pada ayam broiler. Jurnal Agromedia. 32 (1): 54-62.

Mufti, M. 1997. Dampak fotoregulasi dan tingkat protein ransum selama periode pertumbuhan terhadap kinerja burung puyuh penelur. Pascasarjana Institut Pertanian Bogor, Bogor. (Thesis).

Parakkasi, A. 1983. Ilmu nutrisi dan makanan ternak ruminan. Angkasa, Bandung.

Patwary, M., Rahman, M., Barua., Sarkar. and Alam, M. 2013. Study on the growth and development of two dragon fruit (Hylocereus polyrhizus) genotypes. The Agriculturists 11 (2): 52-57.

Rachmat, W., Piliang, W. G., Suhartono, M. T and Manalu, W. 2007. Age maturity of female japanese quails fed diets containing katuk leave meal Sauropus androgynus. Animal Production. 9 (2): 67-72. 
Subekti, E. 2012. Pengaruh penambahan vitamin $\mathrm{C}$ pada pakan non komersial terhadap efisiensi pakan puyuh petelur. Mediagro. 8 (1): 1-8.

Tillman, A. D., Hari, H., Soedomo, R., Soeharto, P dan Soekato, L. 1991. Ilmu makanan ternak dasar. Universitas Gadjah Mada Press, Yogyakarta.

Utari, G. A., Iriyanti, N dan Mugiyono, S. 2013. Kadar total plasma dan glukosa darah pada itik manila yang diberi pakan dengan protein dan energi metabolis yang berbeda. Jurnal Ilmiah Peternakan 1 (3): 1037-1042.

Wahju, J. 2004. Ilmu nutrisi unggas. cetakan V. Gadjah Mada University Press, Yogyakarta.
Widjastuti, T. dan Kartasudjana, R. 2006. Pengaruh pembatasan ransum dan implikasinya terhadap performa puyuh petelurpada fase produksi pertama. Journal Indoesia Tropical Animal Agriculture. 31 (3): 162-166.

Yatno, N. R., Wiryawan, K. G., Setiyono, A., Purwadaria, T dan Hardjosworo, P. 2008. Retensi protein dan nilai energi metabolis konsentrat protein bungkil inti sawit hasil ekstraksi kombinasi fisik-kimiawi. Seminar Nasional Teknologi Peternakan dan Veteriner. Hal : 669-673. 